\title{
HUBUNGAN ANTARA ADVERSITY QUOTIENT DAN STRES PADA ANGGOTA KEPOLISIAN DI POLRESTABES SEMARANG
}

\author{
Ajeng Indy Nadhira dan Ruseno Arjanggi \\ Fakultas Psikologi, Universitas Islam Sultan Agung Semarang
}

Email: ruseno@unissula.ac.id

\begin{abstract}
Abstrak
Penelitian ini bertujuan untuk mengetahui hubungan antara adversity quotient dan tingkat stres pada anggota kepolisian, khususnya polrestabes Semarang. Penelitian ini menggunakan metode classified random sampling sebagai teknik pengambilan sampel dengan menggunakan metode kuantitatif dalam pengambilan sampel. Populasi dalam penelitian adalah anggota kepolisian Polrestabes Semarang khususnya anggota Sat Sabhara, Sat Lantas dan Sat Reskrim. Sampel dalam penelitian ini berjumlah 83 subjek. Pada penelitian ini, alat yang digunakan untuk mengambil data yakni berupa skala yang terdiri dari 2 skala, yakni skala adversity quotient dan skala tingkat stres. Skala adversity quotient disusun berdasakan 4 (empat) aspek, yakni control, origin dan ownership, reach serta endurance. Skala adversity quotient terdiri dari 34 aitem yang memiliki koefisiensi reliabilitas 0.921 dengan indeks daya beda yang bergerak dari 0.321 - 0.635. Skala tingkat stres disusun berdasarkan 3 aspek yakni psikologi, fisik serta perilaku dan terdiri dari 24 aitem dengan koefisiensi reliabilitas 0. 920, indeksi daya beda skala ini bergerak dari $0.351-0.706$. Analisis data pada penelitian ini menggunakan teknik korelasi product moment. Hasil penelitian menunjukkan bahwa hipotesis yang diajukan peneliti dapat diterima yaitu ada hubungan antara adversity quotient dengan tingkat stres pada anggota kepolisian polrestabes. Hasil uji hipotesis menunjukkan bahwa koefisiensi korelasi $r_{x y}=-0.905$, dengan taraf signifikansi $p=0.000(p<0.01)$. Nilai koefisiensi determinasi $\left(r^{2}\right)$ sebesar 0.819 yang menandakan bahwa ada hubungan negatif yang sangat signifikan antara adversity quotient dan tingkat stres pada anggota kepolisian di Polrestabes Semarang serta memiliki sumbangan efektif sebesar $81.9 \%$.
\end{abstract}

Kata Kunci : Adversity Quotient, Stres, Anggota Kepolisian

\section{THE CORELATION BETWEEN ADVERSITY QUOTIENT AND STRESS IN POLICE OFFICER AT POLRESTABES SEMARANG}

\begin{abstract}
This study aims to determine the relationship between adversity quotient and stress level in police officer, especially Polrestabes Semarang. This research uses classified random sampling method as a sampling technique by using quantitative method. The population in this study were police officer in Polrestabes Semarang, especially polce at Sat Sabhara, Sat Lantas and Sat Reskrim members. The sample in this study amounted to 83 subjects. In this study, the tool used to retrieve data is a scale consisting of 2 scales, which is adversity quotient scale and stress level scale. The adversity quotient scale is based on 4 (four) aspects, namely by control, origin and ownership, reach and endurance. The adversity quotient scale consists of 34 items that have a reliability coefficient of 0.921 with a range of index varies moves from $0.321-0.635$. The stress level scale is arranged based on 3 aspects qhich is psychology, physical and behavior. This scale consists of 24 items with reliability coefficient of 0. 920, the index varies moves of this scale start form 0.351 till 0.706. Data analize in this research using product moment correlation technique. The results showed that the hypothesis proposed by the researcher can be accepted that there is a relationship between adversity quotient and stress level in polrestabes policing member. Result of hypothesis test show that correlation coefficient $r_{x y}=-0.905$, with significance level $p=0.000(p<0.01)$. The value of determination coefficient $\left(r^{2}\right)$ is 0.819 which indicates that there is a very significant negative
\end{abstract}


relationship between adversity quotient and stress level in police officer at Polrestabes Semarang and has an effective contribution of $81.9 \%$.

Keywords: Adversity Quotient, Stress, Police Office

\section{Pendahuluan}

Stres adalah kondisi yang dihasilkan oleh adanya tekanan fisik dan psikis yang diakibatkan oleh tuntutan dalam diri dan lingkungan sebagai hasil dari proses adaptasi atau penyesuaian diri (Nevid, Rathus, \& Greene, 2005). Apapun kegiatan yang dikerjakan, setiap individu dapat menemui suatu kejadian, lingkungan, ataupun kelelahan fisik yang dapat memberi tekanan atau stres bagi dirinya. Pelajar, pekerja, ibu rumah tangga dan bahkan seorang pengangguran sekalipun akan menemui stressor atau dengan kata lain akan menghadapi stres. Polisi merupakan salah satu jenis pekerjaan yang juga tidak dapat dihindarkan dari perasaan stres.

Ira Glasser selaku direktur utama ACLU (American Civil Liberties Union) mengungkap bahwa pekerjaan sebagai polisi adalah pekerjaan yang menyangkut banyak aspek, sulit, berbahaya dan stressfull (Amaranto, 2003). Howard (Magdalena, 2008) mengatakan bahwa pekerjaan sebagai polisi dikatakan stressfull karena petugas polisi tidak memiliki kontrol atas lingkungan yang ada disekitarnya dan harus menghadapi pelaku kejahatan yang menyulitkan. Berbagai tuntutan peran dan kewajiban yang harus diemban oleh seorang anggota polri dan tidak diimbangi dengan kemampuan yang mumpuni dari pribadinya akan menimbulkan kesenjangan antara tuntutan dan kenyataan yang ada, sehingga memposisikan pribadi tersebut pada situasi yang penuh tekanan, konflik, dan frustrasi.

Faktor yang diyakini dapat menimbulkan stres yakni persepsi dan penilaian seseorang terhadap situasi serta kemampuannya dalam menghadapi atau mengambil manfaat dari situasi sulit yang dihadapi tersebut (Widyaningrum, 2007). Kemampuan seseorang dalam menghadapi dan mengambil manfaat dari suatu permasalahan atau kesulitan sebagai sebuah tantangan atau peluang untuk menjadi lebih baik dan meraih sukses selanjutnya dikenal dengan sebutan Adversity Quotient. Pada penelitian yang dilakukan oleh Charmila (2013) diketahui bahwa faktor yang memengaruhi perbedaan tingkat stres pada tiap individu yakni; cara coping stres, ketahanan psikologi, kecerdasan emosional, self efficacy, dukungan sosial dan adversity quotient.

Sebuah peleitian yang sebelumnya dilakukan pada mahasiswa memaparkan hasil bahwa adversity quotient dan self eficacy memiliki peran yang cukup berpengaruh pada tingkat toleransi stres individu (So'imah, 2010). Mendukung hasil penelitian tersebut, terdapat penelitian yang dilakukan oleh Shen (2014) dengan judul "The Relative Study of Adversity Quotient, Job Stress, Organizational Commitment and Turnover Intention of Employees in the Traditional Industry" menunjukkan hasil bahwa dimensi adversity quotient memiliki pengaruh pada stres kerja, komitmen organisasi serta keinginan pekerja industri untuk berhenti dari pekerjaan.

Berdasarkan studi pendahuluan, dapat diketahui pula bahwa kemampuan seseorang dalam mengendalikan dan mengatasi situasi sulit (adversity quotient) merupakan salah satu faktor yang berperan penting dalam mempengaruhi tingkat stres anggota kepolisian.

Stres

Stres merupakan keadaan yang memengaruhi tiap dimensi dalam kehidupan seseorang dan dapat menghambat cara berpikir seseorang (Potter \& Perry, 2005). Mc Nemey (dalam Yosep \& Sutini, 2014) menyebutkan bahwa stres merupakan reaksi fisik, mental, dan kimiawi tubuh terhadap situasi yang 
menakutkan, mengejutkan, membingungkan, membahayakan dan merisaukan seseorang. Stres juga dapat dijabarkan sebagai segala masalah atau tuntutan penyesuaian diri yang mengganggu keseimbangan psikosomatososialnya (Smet, 1994).

Berdasarkan pengertian di atas dapat disimpulkan bahwa stres adalah bentuk ketegangan fisik, mental dan kimiawi tubuh sebagai tanggapan atau reaksi seseorang dalam menghadapi kondisi yang menekan serta berbagai tuntutan atau beban yang ditujukan padanya dan bersifat non-spesifik.

Setiap kejadian atau faktor yang mampu menimbulkan respon stres dalam kehidupan manusia dapat disebut dengan stressor. Stressor dapat berasal dari berbagai sumber, baik dari kondisi fisik, psikologis, maupun sosial. Stresor dapat ditemukan diberbagai tempat seperti situasi kerja, dirumah, dalam kehidupan sosial, dan lingkungan luar lain (Hawari, 2013).

Burhanudin (2011) mengungkapkan bahwa faktor yang dapat menimbulkan stres dibagi menjadi dua, yakni faktor internal dan faktor eksternal. Faktor internal yang berpengaruh pada munculnya stres meliputi kepribadian, kemampuan, dan nilai budaya. Sedangkan faktor eksternal dapat meliputi pekerjaan (organisasi) maupun diluar pekerjaan (non organisasi). Atknison (1994) mengungkapkan ada 5 faktor yang dapat memengaruhi stres, yakni kemampuan menerka, kontrol atas jangka waktu, evaluasi kognitif, perasaan mampu; hal ini terkait dengan perasaan seseorang atas kemampuannya mengatasi situasi penuh tekanan, serta dukungan masyarakat.

Menurut Davidson \& Neale (dalam Nasir \& Muhith, 2011) sumber stres berasal dari diri individu, keluarga, komunitas dan masyarakat. Sumber stres yang berasal dari diri individu berkaitan dengan adanya konflik dalam diri. Terdapat dua kecenderungan yang menjadi penarik serta pendorong konflik, yakni approach dan avoidance. Sumber stres yang berkaitan dengan keluarga contohnya seperti adanya anggota baru, kematian anggota keluarga dan adanya anggota keluarga yang sakit.

Peristiwa yang dianggap sebagai stresor oleh individu belum tentu merupakan stressor bagi individu lain. Noermijati (2008) mengungkapkan bahwa kecenderungan individu dalam mengalami stres tergantung pada kemampuan serta kondisi masing-masing individu. Begitu pula reaksi individu terhadap stressor yang sama akan berbeda pula satu dan lainnya (Darmojo, 1985; So'imah, 2010). Korchin (dalam So'imah, 2010) menyebutkan bahwa perbedaan itu disebabkan oleh proses kognitif yang berbeda pada setiap individu. Proses kognitif adalah proses mental dalam menilai stressor serta menilai kemampuan diri untuk mengatasi stressor (Sarafino, 1998). Charmila (2013) mengungkapkan bahwa faktor yang memengaruhi tingkat stres pada tiap individu yakni; cara coping stres, ketahanan psikologi, kecerdasan emosional, self efficacy, dukungan sosial dan adversity quotient.

Rasmun (2004) menjelaskan bahwa sterdapat tiga tingkat kategori stres. Pertama adalah stres ringan yakni kondisi tertekan yang tidak merusak aspek fisiologis dari seseorang. Stres ringan dapat dirasakan oleh setiap individu dan dapat dipicu karena lupa, dikritik, terkena macet serta ketiduran. Stres ringan biasanya terjadi hitungan jam atau bahkan hanya dalam hitungan menit. Situasi ini tidak akan menimbulkan penyakit kecuali jika dihadapi terus menerus.

Kedua adalah stres sedang yang terjadi dalam kurun waktu lebih lama yakni dari beberapa jam samapi beberapa hari. Keadaan yang dapat menimbulkan stres sedang yaknibeban kerja berlebih, mengharapkan pekerjaan baru dan tidak bertemu dengan anggota keluarga dalam waktu yang lama. Stres sedang dan stres berat jika tidak ditangani dengan benar dapat memicu munculnya penyakit atau gangguan mental. 
Ketiga adalah tingkat stres berat (stres kronis) yang telah terjadi dalam kurun waktu beberapa minggu hingga beberapa tahun. Keadaan ini biasanya dipicu akibat tidak harmonisnya hubungan suami istri, keadaan ekonomi yang kurang atau penyakit fisik yang lama.

Tingkat stres pada tiap individu tentu berbeda, perbedaan ini didasari oleh berbagai macam faktor yang memengaruhi seperti cara coping stres, ketahanan psikologi, kecerdasan emosional, self efficacy, dukungan sosial dan adversity quotient (Charmila, 2013). Terdapat 3 (tiga) aspek yang menandakan munculnya stres menurut Beehr \& Newman (Taylor, 2006) aspek psikologis, fisik serta perilaku.

\section{Adversity Quotient}

Adversity quotient dapat diartikan sebagai kemampuan seseorang dalam meraih kesuksesan, ketahanan dan kemampuan seseorang untuk bangkit meraih sukses serta tidak berhenti dalam usahanya. Stoltz (Wahyu, 2010) mendefinisikan adversity quotient sebagai kecerdasan menghadapi rintangan atau kesulitan. Tidak hanya menjelaskan mengenai kemampuan individu dalam mengatasi kesulitan dan meraih kemenangan, namun adversity quotient juga mencakup cara individu dalam mengubah pandangannya terhdapat kesulitan dan menjadikannya sebagai sebuah peluang baru untuk mencapai kesuksesan yang diinginkan.

Stoltz (2005) mengungkapkan bahwa kecerdasan adversity mempunyai tiga bentuk. Pertama, AQ merupakan suatu kerangka kerja konseptual yang baru untuk memahami dan meningkatkan semua segi kesuksesan. Kedua, AQ merupakan suatu ukuran untuk mengetahui respon terhadap kesulitan. Saat ini pola-pola tersebut dapat diukur, dipahami, dan diubah. Ketiga, AQ adalah serangkaian alat yang memiliki dasar ilmiah untuk memperbaiki respon seseorang terhadap kesulitan, yang mampu memperbaiki profesionalitas dan efektivitas pribadi seseorang secara keseluruhan. Gabungan dari ketiga unsur tersebut merupakan sebuah paket yang lengkap nuntuk memahami dan memperbaiki landasan kekuatan dasar seseorang.

Berdasarkan uraian pendapat Stoltz di atas maka dapat disimpulkan bahwa adversity quotient (AQ) adalah kemampuan seseorang dalam menyikapi dan mempersepsi suatu permasalahan atau kesulitan sebagai sebuah tantangan atau peluang untuk menjadi lebih baik dan meraih kesuksesan.

Adversity quotient (AQ) memiliki peranan yang penting dalam kehidupan individu (Stoltz, 2005). Kemampuan individu dalam mempersepsi serta menangani masalah akan menjadi tolak ukur keberhasilannya mengerjakan tantangan serta memecahkan masalah (Laura \& Sunjoyo, 2009). Semakin buruk suatu keadaan, maka akan semakin sedikit orang yang bertahan dalam menghadapi sebuah tantangan. Semakin sulit situasi yang dihadapi, maka akan semakin sedikit orang yang bersedia atau mampu memecahkannya. Hubungan antara harapan (rasa percaya bahwa apa yang dikerjakan akan menuai hasil yang baik), ketidakberdayaan (rasa tidak yakin bahwa apa yang dilakukan akan membuahkan hasil yang baik), dan adversity quotient menunjukan bahwa AQ merupakan kemampuan yang mampu menentukan apakah seseorang tetap memiliki harapan dalam masa sulitnya atau tidak. kemampuan untuk tetap berjuang ketika menghadapi kesulitan ini ditentukan oleh AQ (Matore, et al 2015).

Berdasarkan pemaparan diatas, dapat disimpulkan bahwa adversity quotient (AQ) memiliki peran penting dalam kehidupan individu, kaitannya dengan harapan dan rasa tidak berdaya yang kemudian erat kaitannya dengan kemampuan seseorang untuk tetap berjuang dan tetap memiliki harapan ketika menghadapi kesulitan atau yang dapat disebut dengan $\mathrm{AQ}$. 
Stoltz menyebutkan terdapat 4 (empat) dimensi yang memengaruhi adversity quotient, yakni control, origin and ownership, reach dan endurance. Berdasarkan tingkat adversity quotient-nya kepribadian seseorang dapat dibagi menjadi tiga yaitu quitters, campers dan climber.

\section{Metode Penelitian}

Penelitian ini terdiri dari dua varibel yaitu tingkat stres sebagai variabel tergantung dan adversity quotient sebagai variabel bebas. Populasi yang digunakan dalam penelitian ini yaitu seluruh anggota kepolisian Satuan Sabhara, Satuan Reskrim dan Satuan Lantas Polretabes Semarang. Jumlah sampel sebanyak 83 sampel. Tehnik pengambilan sampel yang di gunakan dalam penelitian ini adalah cluster random sampling.

Teknik pengambilan data pada penelitian ini melalui pengisian skala yang terdiri dari skala tingkat stres dan skala adversity quotient. Skala tingkat stres disusun berdasarkan aspek Beehr dan Newman, terdiri dari 24 aitem yang memiliki indeks daya beda tinggi dengan rentang indeks yang bergerak antara 0,351-0,706 dan koefisien reliabilitas alpha sebesar 0,920. Skala adversity quotient disusun berdasarkan dimensi yang dikemukakan oleh Stoltz, terdiri dari 34 aitem yang memiliki indeks daya beda tinggi dengan rentang indeks yang bergerak pada angka 0.321 hingga 0.635 dengan koefisien reliabilitas alpha sebesar 0,921. Aitem pada skala adversity quotient disusun dengan 4 (empat) alternatif jawaban yakni Sangat Sesuai (SS), Sesuai (S), Tidak Sesuai (TS) dan Sangat Tidak Sesuai (STS). Jawaban diberi nilai secara bertingkat. Jawaban aitem favorable: (SS) mendapat nilai 4, (S) mendapat nilai 3, (TS) mendapat nilai 2, (STS) mendapat nilai 1. Sedangkan norma untuk skoring aitem unfavorable yakni (SS) mendapat nilai 1, (S) mendapat nilai 2, (TS) mendapat nilai 3, (STS) mendapat nilai 4.

Uji validitas yang digunakan dalam penelitian adalah validitas isi. Uji daya beda aitem diukur menggunakan product moment untuk mengetahui korelasi skor aitem. Estimasi reliabilitas menggunakan tehnik alpha cronbach.

\section{Hasil dan Pembahasan}

Sebelum dilakukan uji hipotesis, dilakukan uji asumsi terlebih dahulu. Uji asumsi yang digunakan pada penelitian ini adalah uji normalitas dan uji normalitas. Uji normalitas dilakukan guna mengetahui apakah populasi data berdistribusi normal atau tidak. Data yang diuji adalah sebaran data pada skala adversity quotient dan skala stres. Uji normalitas dalam penelitian ini menggunakan uji One Sample Kolmogorov-Smirnov dengan taraf signifikasi 0,05. Data dinyatakan berdistribusi normal jika signifikasi lebih besar dari $5 \%$ atau 0,05 . Berdasarkan hasil perhitungan uji normalitas yang telah dilakukan pada dua variabel diperoleh hasil nilai K-SZ sebagai berikut:

Tabel 1. Hasil Uji Normalitas

\begin{tabular}{lllllll}
\hline Variabel & Mean & Std Deviasi & KS Z & Sig & P & Keterangan \\
\hline $\begin{array}{l}\text { Adversity } \\
\text { Quotient }\end{array}$ & 107,27 & 16,005 & 0.697 & 0.716 & $>0.05$ & Normal \\
Stres & 46,75 & 11,676 & 0.920 & 0.365 & $>0.05$ & Normal \\
\hline
\end{tabular}


Uji linearitas pada penelitian bertujuan untuk mengetahui secara signifikan apakah kedua variabel memiliki hubungan linear atau tidak. Data dengan nilai signifikansi pada F Linearity kurang dari 0,05 dinyatakan memiliki hubungan linear.

Hasil uji linearitas hubungan antara adversity quotient dan stres mendapatkan Flinear sebesar 366,196 dan angka signifikasi sebesar $0,00(p<0,05)$. Hal tersebut menunjukkan bahwa variabel adversity quotient dan stres memiliki hubungan secara linear.

Hasil analisis pada hipotesis yang diajukan didapatkan hasil bahwa ada hubungan yang sangat signifikan antara adversity quotient dan tingkat stres pada anggota kepolisian di Polrestabes Semarang yang ditunjukkan dengan hasil angka korelasi $r_{x y}$ sebesar -0.905 dan taraf signifikansi sebesar 0,000 $(p<0,01)$. Hubungan antara adversity quotient dan tingkat stres bersifat negative, yang berarti semakin tinggi adversity quotient yang dimiliki individu makan semakin rendah tingkat stres individu tersebut. Sumbangan efektif yang diberikan oleh adversity quotient pada tingkat stres sebesar $81,9 \%$ dan sisanya $18,1 \%$ dipengaruhi oleh faktor lainnya.

Berdasarkan pada mean empirik yang ada pada norma kategorisasi distribusi kelompok sampel dalam penelitian dapat diketahui rentang skor sampel berada dalam kategorisasi tinggi yaitu 107,27.

Adapun norma kategorisasi yang digunakan sebagai deskripsi data variabel secara keseluruhan dapat dilihat pada tabel berikut:

Tabel 2. Kategorisasi skor subjek pada skala Adversity Quotient

\begin{tabular}{llll}
\hline Norma & Kategorisasi & Jumlah & Persentase \\
\hline $115,5 \leq x \leq 136$ & Sangat tinggi & 22 & $26,5 \%$ \\
$95,2<x \leq 115,6$ & Tinggi & 46 & $55,4 \%$ \\
$74,8<x \leq 95,2$ & Sedang & 12 & $14,5 \%$ \\
$54,4<x \leq 74,8$ & Rendah & 2 & $2,4 \%$ \\
$34<x \leq 54,4$ & Sangat rendah & 1 & $1,2 \%$ \\
& Total & 83 & $100 \%$ \\
\hline
\end{tabular}

Berdasarkan norma kategorisasi normal kelompok sampel dalam penelitian ini dapat diketahui bahwa menurut rerata empirik (mean) sebesar 46,77 . Hal ini menandakan bahwa mean berada dalam kategori rendah. Adapun norma kategorisasi yang digunakan sebagai deskripsi data variabel secara keseluruhan dapat dilihat pada tabel berikut:

Tabel 3. Kategorisasi skor subjek skala stres

\begin{tabular}{llll}
\hline Norma & Kategorisasi & Jumlah & Persentase \\
\hline $81,5<x \leq 96$ & Sangat tinggi & 0 & $0 \%$ \\
$67,2<x \leq 81,6$ & Tinggi & 0 & $0 \%$ \\
$52,8<x \leq 67,2$ & Sedang & 3 & $3,6 \%$ \\
$38,4<x \leq 52,8$ & Rendah & 16 & $19,3 \%$ \\
$24<x \leq 38,4$ & Sangat rendah & 64 & $77,1 \%$ \\
\hline & Total & 83 & $100 \%$ \\
\hline
\end{tabular}

Penelitian terdahulu yang dilakukan oleh Tricahya (2010) mengenai hubungan antara adversity quotient dan stres yang dilakukan pada mahasiswa yang bekerja, diketahui bahwa terdapat hubungan negatif antara adversity quotient dengan stres. Hal ini dibuktikan dengan hasil koefisien korelasi sebesar -0,329 dan taraf signifikansi sebesar 0,003. Hasil tersebut menandakan apabila individu memiliki adversity quotient tinggi, maka tingkat stres individu tersebut akan lebih rendah, begitupun sebaliknya. 
Hasil studi pendahuluan melalui wawancara dan observasi menunjukkan bahwa anggota kepolisian cenderung memiliki tingkat stres yang tinggi karena kurang memiliki kemampuan untuk memersepsi dan mengatasi tekanan. Sedangkan, berdasarkan hasil uji hipotesis didapatkan bahwa tingkat stres anggota kepolisian Polrestabes Semarang berada pada kategori rendah. Hal ini menandakan bahwa terjadi ketidaksesuaian antara studi pendahuluan dengan hasil uji hipotesis. Faktor yang dapat mempengaruhi perbedaan hasil ini yakni sampel observasi dan wawancara yang kurang representatif dengan jumlah populasi, selain itu faktor perputaran shift pada anggota yang menjadi responden juga ikut memiliki peran dalam perbedaan hasil.

Hambatan hidup serta situasi sulit yang dirasakan seseorang dapat diatasi dengan adversity quotient yang mumpuni dari individu tersebut. Sebab, adversity quotient yang mumpuni merupakan salah satu faktor yang dapat membuat individu tumbuh sebagai pribadi yang pantang menyerah (Stoltz, 2005). Penyataan tersebut memperkuat hasil penelitian yang telah dilakukan oleh peneliti. Kemampuan seseorang dalam menghadapi serta mengatasi kesulitan atau yang disebut dengan adversity quotient dekat kaitannya dengan perbedaan tingkat stres pada tiap individu. Lasmono (2001) menjelaskan bahwa seseorang dengan adversity quotient yang tinggi merupakan individu yang tegar dalam menghadapi serta mengatasi kesulitan yang menghampirinya.

Berdasarkan penelitian sebelumnya yang dilakukan oleh Inayatillah (2015) dapat diketahui apabila mahasiswa memiliki adversity quotient yang baik (bernilai tinggi) maka mahasiswa tersebut tidak akan mudah merasa tertekan (stres). Hal tersebut menandakan bahwa individu pada dasarnya memiliki cara efektif untuk menghadapi stres serta membentuk pengalaman menghadapi stres menjadi toleransi stres pada diri jika memiliki adversity quotient yang baik.

Hasil analisis pada penelitian yang dilakukan peneliti didapatkan bahwa sebagian besar anggota kepolisian Polrestabes Semarang pada satuan sabhara, reskrim dan lantas memiliki adversity quotient pada kategori tinggi. Hal tersebut dilihat berdasarkan mean yang diperoleh yakni sebesar 107,27. Hasil tersebut menandakan bahwa anggota kepolisian Polrestabes Semarang dapat dikatakan sebagai individu yang mampu mengendalikan situasi sulit, pantang menyerah serta memiliki semangat dan memiliki pemikiran positive ketika dihadapkan pada situasi yang kurang menguntungkan. Hal ini dapat diperoleh dari pengelompokkan kepribadian individu dengan didasarkan pada tingkat adversity quotient yang dimiliki.

Hasil analisis pada tingkat stres sebagian besar berada dalam kategori rendah, yakni dengan nilai mean empirik sebesar 46,77. Hal ini menandakan bahwa anggota kepolisian Polrestabes Semarang pada satuan sabhara, reskrim dan lantas mampu mengendalikan diri dengan baik saat dihadapkan dengan situasi yang menekan. Tingkat stres yang rendah pada anggota kepolisian tidak hanya didasarkan pada adversity quotient yang baik, namun juga didasarkan pada pembagian shift kerja. Individu dengan shift kerja pagi cenderung memiliki tingkat stres yang lebih rendah dibandingkan dengan individu yang mendapatkan shift kerja malam (Sumarto, 2016). Anggota kepolisian Polrestabes Semarang yang menjadi responden pada penelitian ini sebagian besar sedang mendapat tugas jaga pada shift pagi. Maka dari itu berdasarkan hasil penelitian yang dilakukan, didapatkan hasil tingkat stres pada kategori rendah.

Berdasarkan hasil penelitian tersebut, dapat dinyatakan bahwa anggota kepolisian Polrestabes Semarang memiliki kemampuan untuk menghadapi serta mengendalikan situasi sulit yang baik dan dapat terhindar dari keadaan stres yang dapat mengganggu kesehariannya. Sumbangan efektif yang diberikan oleh adversity quotient sebesar $81,9 \%$ dan sisanya $18,1 \%$ dipengaruhi oleh faktor lainnya. 


\section{Kesimpulan}

Berdasarkan hasil penelitian dan uji hipotesis dapat diketahui bahwa ada hubungan yang signifikan antara adversity quotient dan tingkat stres pada anggota kepolisian Polrestabes Semarang. Oleh karena itu hipotesis yang diajukan peneliti dapat dikatakan diterima, dengan diketahui tingkat adversity quotient anggota kepolisian berada pada kategori tinggi dan tingkat stres berada pada kategori rendah.

\section{Daftar Pustaka}

Amaranto, E. (2003). Police stress intervention : brief treatment and crisis intervention, 3 (1), 47-53.

Andriyanto, R. (2014). Perbedaan pola pikir kewirausahaan dan adversity quotient pada mahasiswa psikologi universitas negeri malang yang berorientasi terhadap pencipta lapangan kerja dan percari kerja. e-Journal Psikologi, 4, 1-12

Atknison, R., Atkinson, C., Smith, E., \& Bem, J. (1994). Pengantar psikologi I. (Taufik \& B. Rukmini, Eds.) (Edisi 8). Jakarta: Penerbit Erlangga.

Azwar, S. (2000). Reliabilitas dan validitas. Yogyakarta: Pustaka Pelajar.

Azwar, S. (2008). Penyusunan skala psikologi. Yogyakarta: Pustaka Pelajar.

Burhanudin. (2011). Perilaku organisasional. Yogyakarta: CAPS.

Charmila, S. (2013). Hubungan adversity quotient dengan tingkat stres pada Mahasiswa tahun pertama fakultas kedokteran universitas riau.Journal Online Mahasiswa Bidang Kedokteran. 57-71

Hawari, D. (2013). Manajemen stres, cemas dan depresi. Jakarta: FKUI.

Inayatillah, V. (2015). Hubungan antara adversity quotient dengan kecenderungan stres dalam menyelesaikan tugas akhir (penulisan skripsi) pada mahasiswa. Skripsi. UIN Sunan Ampel, Surabaya

Jayanegara. (2007). Stres kerja dan coping pada polisi indonesia. Jakarta: Universitas Indonesia Press.

Lasmono, H. . (2001). Tinjauan singkat adversity quotient. Indonesian Psychological Journal, 17(1), 6368.

Laura, \& Sunjoyo. (2009). Pengaruh adversity quotient terhadap kinerja karyawan, sebuah studi kasus pada holiday inn bandung. In National Symposium Management Departement Economic Faculty Maranata Chirstian University (pp. 369-393). Bandung

Lutfiyah. (2011). Analisis faktor-faktor yang mempengaruhi stres kerja pada polisi lalu lintas. Skripsi. Universitas Islam Negeri, Jakarta.

Magdalena. (2008). Hubungan antara stres dan kepuasan kerja pada polisi wanita. Universitas Indonesia, Jakarta.

Matore, M. ., Khairani, A. ., \& Razak, N. (2015). The influence of AQ on the academic achievement among malaysian polyttechnic students. International Education, 8, 69-74. 
Morash, M., \& Haarr, R. (2006). Multilevel influence on police stress, 22(1), 26-43. Retrieved from hSttps://msu.edu/ kwakdaeh/merry(2005).pdf

Nasir, A., \& Muhith, A. (2011). Dasar dasar keperawatan jiwa. Jakarta: Salemba Medika.

Nevid, J. ., Rathus, S. ., \& Greene, B. (2005). Psikologi Abnormal. Jakarta: Penerbit Erlangga.

Potter, \& Perry. (2005). Buku ajar fundamental keperawatan: konsep, proses dan praktik. Jakarta: EGC.

Rasmun. (2004). Stres, koping dan adaptasi teori dan pohon masalah keperawatan. Jakarta: CV. Sagung Seto.

Robbins, S. (2001). Perilaku organisasi edisi 8. Prentice Hall.

Sarafino, E. . (1998). Health psychology biopsychosocial interaction. New York: John Wiley\&Sons, Inc.

Shen, C. (2014). The relative study of gender roles, and job stress and adversity quotient. The Journal of Global Business Management.10(1), 19-32.

Smet, B. (1994). Psikologi kesehatan. Jakarta: Gramedia.

So'imah, D. (2010). Hubungan adversity quotient dan self efficacy dengan toleransi terhadap stres pada mahasiswa. Skirpsi. Universitas Sebelas Maret, Surakarta

Solis, D., \& Lopez, E. (2015). Stress level and adversity quotient among single working mothers. Asia Pacific Journal of Multidiciplinary Research, 3(5). https://doi.org/2350-7756 E-ISSN 23508442

Stoltz, P. (2005). Adversity quotient: mengubah hambatan menjadi peluang. (Y. Hardiwati, Ed.) (cetakan ke 6). Jakarta: PT. Grasindo.

Stoltz, P. G. (2003). Adversity quotient. Jakarta: Grasindo.

Sugiyono. (2007). Statistika untuk penelitian. Bandung: CV. Alfabeta.

Sumarto, I. (2016). Perbedaan stres kerja ditinjau dari shift kerja pagi siang dan malam pada perawat di rumah sakit umum daerah kota kendari tahun 2016. Jurnal Ilmu Kesehatan Masyarakat.1(3). 1-7

Tarwaka. (2004). Ergonomi untuk keselamatan, kesehatan kerja dan produktivitas. Surakarta: UNIBA Press.

Taylor. (2006). Health psychology. Singapore: Mc. Graw Hill.

Tricahya, F. (2010). Hubungan antara adversity quotient dan stres pada mahasiswa yang bekerja.Jurnal Psikologi, 3, 10-20.

Widyaningrum, J. R. (2007). Adversity intelligence dan prestasi belajar siswa. Jurnal Psikologi Proyeksi, $2(2), 47-56$.

Yosep, I., \& Sutini, T. (2014). Buku ajar keperawatan jiwa (dan advance mental health nursing). Bandung: Refika Aditama. 
Ajeng Indy Nadhira dan Ruseno Arjanggi

Yusuf. (2009). Stress. Retrieved from www.metro-polri.go.id/stress

Zahreni, S., \& Malini, S. (2014). Hubungan adversity quotinet dengan kepuasan berwirausaha pada wirausaha wanita di kota Medan. Jurnal Ekonom, XVII, 6-12.

Zhi-hsien, C. V. (2014). A study investigating the influence of demographic variables on adversity quotient. Journal of Human Resource and Adult Learning, 10(6), 22-32. Retrieved from http://www.hraljournal.com/Page/3 Shen Chao Ying.pdf 